\title{
Immigration and Housing Booms: Evidence from Spain
}

July 2009

\author{
Libertad Gonzalez \\ Universitat Pompeu Fabra
}

\author{
Francesc Ortega \\ Universitat Pompeu Fabra
}

\begin{abstract}
We estimate empirically the effect of immigration on house prices and residential construction activity in Spain over the period 1998-2008. This decade is characterized by both a spectacular housing market boom and a stunning immigration wave. We exploit the variation in immigration across Spanish provinces and construct an instrument based on the historical location patterns of immigrants by country of origin. The evidence points to a sizeable causal effect of immigration on both prices and quantities in the housing market. Between 1998 and 2008 , the average Spanish province received an immigrant inflow equal to $17 \%$ of the initial working-age population. We estimate that this inflow increased house prices by about $52 \%$ and is responsible for $37 \%$ of the total construction of new housing units during the period. These figures imply that immigration can account for roughly one third of the housing boom, both in terms of prices and new construction.
\end{abstract}

Keywords: housing market, immigration, house prices, construction, Spain.

JEL Codes: F22, J61, R21, R23, R31. 


\section{Introduction}

Over the course of the last decade, Spain experienced a spectacular boom in house prices. Between 1998 and the peak of the boom in 2008 (see Figure 1.1), housing prices increased by $175 \%$, from 760 to 2,100 euros per square meter (Spanish Ministry of Housing). ${ }^{1}$ In comparison, house prices in the US increased by $104 \%$ between the peak in 2007 and ten years earlier (Freddie Mac CMHPI). ${ }^{2}$ The large increase in housing prices in Spain is even more striking when we take into account the large increase in residential construction activity during the period. Between 1998 and 2008, the share of construction in Spain's GDP increased by four percentage points, reaching $10.7 \%$ in $2008 .^{3}$

The causes of the recent housing boom in Spain, and elsewhere, are still not well understood. Many factors seem to have played a role: unprecedented low interest rates, deregulation in the mortgage market, rising income, irrational exuberance, and so on. Perhaps with the exception of Spain's vigorous economic growth during the decade, most of the other factors are common across EU member states and the US. Thus they provide little insight on why Spain experienced a relatively larger boom in the housing market.

We hypothesize that immigration may explain Spain's larger housing market boom, relative to the US and other European countries. Over the last decade, Spain received a stunning wave of immigration, topping international rankings both in absolute terms and relative to population. Between 1998 and 2008, the foreign-born share in the working age population increased from 2 to $16 \%$ (Local Population Registry). In absolute terms, the foreign-born population increased

\footnotetext{
${ }^{1}$ Over the same time period the total percentage increase in the consumer price index in Spain was $61.5 \%$. That is, an average annual inflation rate of $4.9 \%$.

${ }^{2}$ Freddie Mac's Conventional Mortgage Home Price Index (CMHPI) provides a measure of typical price inflation for houses within the US. For more details see http://www.freddiemac.com/finance/cmhpi.

3 The GDP share of the construction sector in the US ranged between $4.1 \%$ and $4.9 \%$ over the period $1998-2008$. For the EU15, it increased from 5.5\% to 6\% between 2000 and 2005.
} 
from barely half a million to 5 million over the course of the decade. The mechanism we have in mind is simple: the large increase in the working-age, foreign-born population would have dramatically boosted the demand for housing in Spain.

The main goal of this paper is to isolate the role played by immigration in the housing market boom in Spain. We focus on two outcomes: housing prices and the flow of new residential construction units. ${ }^{4}$ Methodologically, we exploit the large regional variation in immigration flows across Spain and use instrumental variables to identify the causal effect of immigration, both on house prices and on housing supply at the regional level.

Based on our instrumental variables estimates, immigration into a province leads to sizeable increases in the price of housing and in construction activity. An increase in the foreign-born population equal to one percent of the total population leads to an increase in house prices of $3.2 \% .{ }^{5}$ In terms of quantities, an inflow of 100 immigrants leads to the construction of about 46 new housing units.

Methodologically, our paper is closely related to the literature studying the causal effects of immigration on housing prices and rents in the US using a spatial correlations approach. ${ }^{6}$ Saiz (2007) estimates the effects of immigration on housing prices and rents in US metropolitan areas. According to his instrumental variables estimates, an immigration flow that increases population by one percent leads to a $1 \%$ increase in rents and a $3 \%$ increase in house prices. ${ }^{7}$ Ottaviano and Peri (2007) investigate empirically the effects of immigration on the labor and rental markets

\footnotetext{
${ }^{4}$ We cannot study housing rents as the data are not available. This is not a terrible omission because the rental market in Spain is relatively small, as a result of many decades of heavy regulation. According to the 2001 Census, only $11 \%$ of the Spanish population lived in rental units in 2001.

${ }^{5}$ That is, 45 euros per square meter of housing relative to a mean of 1,384 euros (national mean, 1998-2008).

${ }^{6}$ See Dustmann, Frattini and Glitz (2008) for an overview of the spatial correlations approach and alternative approaches to estimating the effects of immigration.

${ }^{7}$ Saiz (2003) analyzes the effect of the 1980 Mariel Boatlift on Miami's housing market.
} 
using data for US states. ${ }^{8}$ Their estimates suggest that the rent-elasticity of immigration is around 0.7, and between 1 and 2 for housing prices. Greulich et al. (2004) focus on the housing consumption patterns of immigrants. ${ }^{9}$

Our paper is also related to two other strands of literature. First, it relates to the recent work on the effects of immigration on the price level and, in particular, on the prices of non-traded goods. Some important recent contributions are Cortes (2008) for the US and Frattini (2009) for the UK. ${ }^{10}$ Second, our paper also touches upon the recent literature studying the effects of the recent wave of immigration on the Spanish labor market. Some important contributions are Carrasco, Jimeno and Ortega (2008), Amuedo-Dorantes and De la Rica (2008), and Gonzalez and Ortega (2008), among others.

This paper makes several contributions to our understanding of the effects of immigration on the housing market. First, we look at an episode --the recent housing market boom in Spain--, which has not been studied in connection to immigration and that has some important features that make it interesting in a wider context. First, the magnitudes of the boom in both housing prices and residential construction activity have been very large relative to other countries. Second, the housing boom coincided in time with an extraordinary immigration wave, quite unique both in terms of the size of the inflows and its rapid acceleration.

Second, we focus not only on house prices, as is common in the US literature, but also analyze directly the effect on housing supply, by looking at new residential construction. This

\footnotetext{
${ }^{8}$ Ottaviano and Peri $(2005,2006)$ also study the relationship between immigration and housing prices, although that is not the main focus of those papers.

${ }^{9}$ These authors also examine the effect of immigration on housing rents across US metropolitan areas, but they do not address endogeneity problems.

${ }^{10}$ Lewis (2003) analyzes the effects of immigration on the structure of production of US states, distinguishing between traded and non-traded sectors.
} 
provides a more comprehensive picture of how the housing market responded to the immigration shock.

Finally, we are able to use high-quality Local Registry data that allow us to measure regional immigrant concentration with precision at the yearly level, as opposed to having to rely on decennial Census data, as is typically the case in the US literature. ${ }^{11}$ This allows us to compare long-differences estimates with a higher-frequency analysis.

The remainder of the paper is organized as follows. Section 2 describes the spatial correlations approach and our instrument. Section 3 presents our data sources and descriptive statistics for the main variables used in the analysis. Section 4 contains our main results and sensitivity analysis, and Section 5 concludes. Figures and tables are located at the end of the paper.

\section{Methodology}

We estimate the impact of immigration on prices and quantities in regional housing markets. We consider two dependent variables: the annual change in the price per square meter of housing (in euros) and the flow of new construction units in a given year. Our main explanatory variable is the increase in the foreign-born population relative to total population. Specifically, our regression model for housing prices is:

$$
\Delta \mathrm{P}_{\mathrm{it}}=\beta \Delta \mathrm{FB}_{\mathrm{it}} / \mathrm{Pop}_{\mathrm{i}, \mathrm{t}-1}+\gamma \mathrm{X}_{\mathrm{it}}+\lambda_{\mathrm{t}}+\rho_{\mathrm{r}}+\lambda_{\mathrm{t}} \cdot \rho_{\mathrm{r}}+\varepsilon_{\mathrm{it}},
$$

where $\Delta \mathrm{P}_{\mathrm{it}}$ is the change in the average euro price of a square meter of housing in province $\mathrm{i}$ between years t-1 and t. Because of the first-difference nature of our dependent variables (the

\footnotetext{
${ }^{11}$ In the labor market context, Aydemir and Borjas (2005) have argued that measuring immigrant concentration using the usual samples of Census data may lead to severe attenuation bias in the estimates. Arguably, our estimates based on Registry data do not suffer from this bias (Farre, Gonzalez and Ortega, 2009).
} 
change in housing prices and the flow of new construction), time-invariant, province-specific factors that affect the level of housing prices have been differenced out. The main explanatory variable, $\Delta \mathrm{FB}_{\mathrm{it}} / \mathrm{Pop}_{\mathrm{i}, \mathrm{t}-1}$, is the increase in the (working-age) foreign-born population in the province during a given year, relative to the total population in the previous year.

Vector $\mathrm{X}_{\mathrm{it}}$ includes a set of controls for macroeconomic conditions, such as GDP growth and the change in the employment-population ratio at the province level. In addition, we include year dummies $\left(\lambda_{t}\right)$ and a set of region dummies $\left(\rho_{\mathrm{r}}\right)$, which effectively allow for different trends in housing prices at the regional level. In particular, we define seven groups of provinces, which we refer to as regions. Finally, we also include region-year dummies $\left(\lambda_{t} \rho_{\mathrm{r}}\right)$, intended to capture region-specific business cycles. For consistency with the previous literature, ${ }^{12}$ we also estimate an additional specification including time-invariant province characteristics or "amenities", such as weather, crime and surface area.

The main coefficient of interest is $\beta$, which captures the effect of immigration on the price of a square meter of housing. To the extent that immigration into a province increases population, we would expect an increase in the demand for housing, leading to an increase in prices (and thus a positive $\beta$ ). It is also possible that $\beta$ takes a value of zero, which would be the case under perfect displacement of natives, that is, if an inflow of foreign-born individuals triggers an equally sized outflow of natives. Immigration might also plausibly reduce housing prices (negative $\beta$ ). This would be the case if immigrants concentrate heavily in the construction sector and larger inflows lead to lower wages in the sector. In sum, the sign and magnitude of the effect of immigration on housing prices is a priori ambiguous.

${ }^{12}$ See, for example, Saiz (2007). 
We estimate a parallel specification to analyze the effects of immigration on the construction of new housing units:

$$
\Delta \mathrm{Q}_{\mathrm{it}} / \mathrm{Pop}_{\mathrm{it}-1}=\beta \Delta \mathrm{FB}_{\mathrm{it}} / \mathrm{Pop}_{\mathrm{it}-1}+\gamma \mathrm{X}_{\mathrm{it}}+\lambda_{\mathrm{t}}+\rho_{\mathrm{r}}+\lambda_{\mathrm{t}} \cdot \rho_{\mathrm{r}}+\varepsilon_{\mathrm{it}}
$$

where the dependent variable is the flow of new housing units built in period $t$ in province $i$, normalized by total population in the previous year. The right-hand side of the regression is identical to the regression model for the change in housing prices. We also estimate additional specifications where both quantities and migrant inflows are introduced without normalizing by population.

Coefficient $\beta$ in (2) captures the effect of immigration, defined as the increase in the foreignborn population relative to the total population in the previous year. We expect $\beta$ to take values between zero and one. If immigrants increase the demand for housing (or increase supply by lowering costs), they would lead to an increase in residential construction. However, if native outflows displace immigrants perfectly, or if immigrants tend to rent instead of buy, the demand effect would be neutralized.

Despite including the macroeconomic controls and the regional trends, estimation of $\beta$ in regression models (1) and (2) may still suffer an endogeneity bias. The sign of the bias is difficult to predict ex ante. Suppose that, for some reason, a province becomes more attractive. As a result, the demand for housing in that province would increase, leading to higher prices, and, simultaneously, more population (native and foreign-born) would flow into the region. This would induce an upward bias in OLS estimates of $\beta$ in (1) and (2). However, the bias could very well go in the opposite direction. Since we are controlling for economic conditions in the province, it is reasonable to expect that immigrants will choose provinces where house prices are rising more slowly, among locations with similar changes in employment rates or GDP. 
In order to overcome the potential endogeneity problem, we follow an instrumental variables approach. As in Saiz (2007) and Ottaviano and Peri (2007), we instrument actual immigrant inflows into a province using historical information on immigrant networks defined by country of origin (a la Card 2001). We expect current location decisions of immigrants to be influenced by the location decisions of earlier immigrants from the same country of origin. If those previous immigrant settlements were established far back enough in time, their geographical distribution should be uncorrelated with the current province-level distribution of shocks to the demand for housing. This type of instrument has been widely used in the literature on the labor market effects of immigration.

Specifically, we define the following predictor of the current stock of foreign-born population in province $\mathrm{i}$ and year $\mathrm{t}$ :

$$
Z_{i, t}=\sum_{c}\left(\frac{F B_{c, i, t_{0}}}{F B_{c, t_{0}}}\right) \cdot F B_{c, t}, \quad \text { for } \mathrm{t}_{0}<\mathrm{t},
$$

where $\mathrm{FB}_{\mathrm{c}, \mathrm{i}, \mathrm{t} 0}$ is the number of individuals born in foreign country $\mathrm{c}$ that inhabited province $\mathrm{i}$ in some base year $\mathrm{t}_{0}$. Thus, the term in parenthesis is the share of c-born individuals that lived in each province in the base year, which provides a measure of the size of that source country network in each province. The only time-varying term in (3) is $\mathrm{FB}_{\mathrm{c}, \mathrm{t}}$, the stock of individuals originated from country c that live in Spain in year t. Hence, an inflow of, say, Polish immigrants into Spain in 2006 will lead to a predicted contemporaneous increase in the Polish population in each province that is proportional to the size of the Polish network in that province in the base year. In practice, we instrument $\Delta \mathrm{FB} / \mathrm{Pop}$ with $\Delta \mathrm{Z} / \mathrm{Pop}$. 


\section{Data and Descriptive Statistics}

\subsection{Data sources and variable definition}

The two dependent variables, house prices and construction of new dwellings at the province and year level, are extracted from official data made publicly available by the Spanish Housing Ministry. ${ }^{13}$ The data on prices per square meter are provided at the quarterly level; we use only $2^{\text {nd }}$ quarter prices in order to minimize seasonality. The data include sales of both new and old dwellings. The data on quantities measure the number of new dwellings completed during a given year.

We measure total (working-age) population and foreign-born population by province and year using the Local Population Registry provided by the National Statistical Institute. ${ }^{14}$ These data are available yearly only from 1998 on, which limits the period of our analysis to 19982008. The high quality of the Registry data allows us to measure immigrant densities at the yearly level and by province with a high level of precision.

Since our population data refer to January $1^{\text {st }}$ of each year, our main explanatory variable is in effect lagged by one year with respect to the housing market variables. For instance, the number of dwellings built during 2008 is estimated to be a function of the increase in the foreign-born population in the province between January $1^{\text {st }}, 2007$ and January $1^{\text {st }}, 2008 .^{15}$

As macroeconomic controls, we use the male employment-population ratio (EPR), constructed from Spanish Labor Force Survey data, and provincial GDP, publicly provided by the National Statistical Institute. As of now, GDP figures are only available up to 2006.

\footnotetext{
${ }^{13}$ See www.mviv.es.

${ }^{14}$ See www.ine.es.

${ }^{15}$ We also experiment with more lags of the explanatory variables (see robustness checks in section 4.4).
} 
We also use time-invariant, province-level "amenities": a measure of crime rates, three weather-related variables, and the surface area of each province. We obtained these data from the publicly available tables issued by the National Statistical Institute. The crime variable measures the number of sentenced crimes in year 2000, and we normalize it by population in the province. The weather variables are the annual number of sunny days, the number of days below freezing (under 0 degrees Celsius), and the annual precipitation, all measured in year 2000.

Finally, the instrument is constructed using Registry data to measure the national annual migration inflow by country of origin, and 1991 Census data to construct early migrant settlement patterns by province, also by source country. ${ }^{16}$ Since the 1991 Census captures immigrants that arrived in Spain in 1990 or earlier, the lag with respect to our period of interest is between 8 and 18 years.

\subsection{Descriptive Statistics}

Table 1 contains the summary statistics for all variables used in the analysis. The number of observations is 500, that is, 50 Spanish provinces times the 10 one-year intervals from 1998 to $2008 .^{17}$

The average increase in housing prices across provinces and years was 136 euros per year. Panel 1 of Figure 1 shows that the average (national) price level was 760 euros per square meter in 1998, reaching almost 2,100 euros in 2008. This implies a $175 \%$ increase over the whole period. The annual growth rate was on average above $10 \%$. It started below $5 \%$ in 1998 ,

\footnotetext{
${ }^{16}$ The 1991 Census groups countries of origin for the foreign-born population into 16 broader "regions".

${ }^{17}$ We omit from the analysis the two Spanish provinces located in North Africa (Ceuta and Melilla). They are very small in size and outliers regarding the foreign-born share.
} 
increased steadily to reach $19 \%$ in 2003 , and fell sharply after 2005 . By the end of 2008 , housing prices had started to fall. ${ }^{18}$

There was a great deal of variation across provinces in both the initial level and the change in prices over the period (see Figure 2). Between 1998 and 2008, the total price increase at the province level ranged from 526 to 2,074 euros (with a median of 1,057 euros). Madrid and Barcelona (the two most populated metropolitan areas) were among the top 5 provinces in terms of price increases during the period.

Panel 2 of Figure 1 illustrates the large construction boom in terms of the number of new dwellings built annually. Roughly 225,000 new dwellings were built nationally in 1998 . Construction activity increased practically in every year until peaking at 600,000 units in 2006 , and started falling after that. The total increase in construction activity between 1998 and 2008 amounted to an impressive $262 \%$. There was also an increase in new dwellings per capita. In 1998, 8 new dwellings were completed per 1,000 working-age individuals. The analogous figure was 20 in 2006.

Residential construction activity also varied a lot across provinces (see Figure 3). Roughly speaking, construction of new housing was most intense along the Mediterranean coast and around Madrid. Between 1998 and 2008, the number of new dwellings built by province ranged from about 12,000 to more than 450,000 . In terms of absolute figures, construction was the largest in Barcelona and Madrid. However, once we normalize by initial population (Figure 3), the flow of new construction in these two provinces is less impressive (below the $30^{\text {th }}$ percentile). ${ }^{19}$

\footnotetext{
${ }^{18}$ The fall cannot be seen in the graph because it started in the last two quarters of the year.

${ }^{19}$ This may reflect space constraints in high-density urban areas. The unavailability of land provides greater incentives to reform older housing units rather than demolishing older units and replacing them with new buildings.
} 
In the quantities analysis (equation 2), we experiment with two dependent variables: the annual number of new dwellings by province, and the same variable normalized by population in the previous year. Table 1 shows that, on average, there were 16.9 new dwellings built annually per 1,000 working-age individuals. In absolute terms, 20,375 new housing units were built annually on average across all provinces and years.

Turning to immigration flows (our main explanatory variable), the foreign-born share in the working-age population increased from 2 to $16 \%$ nationally between 1998 and 2008, as illustrated by Figure 1 (panel 3). In levels, the foreign-born population increased from less than 500,000 to 5 million, while the total (working-age) population increased from 26.7 to 31.3 million. This implies that immigration was responsible for $98 \%$ of total population growth during the period.

In the 2008 cross-section, the foreign-born share ranged from 4 to $27 \%$ across provinces (Figure 4). Immigrant concentration was highest along the Mediterranean coast, in the islands and around Madrid. Note that the cross-section of foreign-born shares at the end of the decade is very similar to the cross-sectional distribution of construction activity over the whole decade, as depicted in Figure 3.

Figure 5 provides a graphical illustration of the correlation between immigration inflows and the housing market variables. The horizontal axis (in both panels) is the change in the foreignborn share in the working-age population between 1998 and 2008, by province. The values range from 4 to 22 percentage points. In the first panel, the vertical axis shows the total change in housing prices during the period. We also include a linear fit. There is a clear positive association between immigration flows and housing prices. ${ }^{20}$ The coefficient on the foreign-born share (from the OLS regression shown in the graph) is significant at the $95 \%$ confidence level. In the second

\footnotetext{
${ }^{20}$ A 10-point increase in the foreign-born share is associated with a price increase of 220 euros.
} 
panel, the vertical axis reports the number of new dwellings built over the decade, normalized by the 1998 population in each province. Provinces with higher migration inflows were also characterized by higher residential construction activity, relative to initial population. ${ }^{21}$

In the next section, we provide a more formal analysis by estimating equations (1) and (2) at an annual frequency and accounting for the potential endogeneity issues by using instrumental variables.

\section{Results}

This section presents our estimates for the effects of immigration on housing markets, both regarding prices and quantities. We begin by presenting the first-stage results, and then discuss the OLS and IV estimates.

\subsection{First-stage regressions}

Table 2 reports the first-stage regressions associated to our main specifications. The dependent variable is the change in the foreign-born population in a province over the total population in the previous year. The main explanatory variable is the instrument: the change in the predicted foreign-born population relative to the total initial population. ${ }^{22}$

The first specification includes no controls other than year dummies. Column 2 adds macroeconomic controls (GDP and employment-population ratios) at the province level. Column 3 includes time-invariant amenities (weather, crime and surface area). Column 4 includes 7 region dummies (but excludes amenities and macro controls), and column 5 further includes

\footnotetext{
${ }^{21}$ The coefficient is significant at the $99 \%$ confidence level, and suggests that a 10-point increase in the foreign-born share is associated with the construction of 113 new dwellings per 1,000 individuals.

${ }^{22}$ Note that specification 6 features absolute changes in both the foreign-born population and the instrument.
} 
region-specific year dummies. Column 6 is comparable to column 1 but without normalizing by initial population.

Across the different specifications, the estimated coefficient ranges from 0.19 to 0.89 , with tstatistics uniformly above 5. For our preferred specification (column 5) the coefficient is 0.19 , with an associated t-statistic of 5.4, which allows us to reject the null hypothesis of weak instruments.

\subsection{House prices}

Let us now turn to our estimates of the effects of immigration on housing prices. Our dependent variable is the change in the price of housing (per square meter) in euros. The main explanatory variable is the change in the foreign-born population relative to total population in the previous year (see equation 1).

Table 3 reports our estimates. Column 1 reports the basic specification, including only year dummies as controls. Column 2 controls for changes in economic conditions at the province level. Column 3 also includes a vector of time-invariant amenities (surface area, crime rates, and weather-related variables). Specification 4 includes regional dummies in an attempt to capture unobservable geographical differences in trends, due to, for example, changes in policies or regulations across different regional governments (excluding the macro controls and amenities). ${ }^{23}$ Specification 5 also includes region-year dummies. This is our preferred specification, since it controls for time-invariant regional characteristics (as in specification 4) as well as for differences in business cycles across regions. All our regressions are populationweighted, and we report heteroskedasticity-robust standard errors.

\footnotetext{
${ }^{23}$ We partition the 50 provinces into 7 regions.
} 
The top panel in table 3 displays the OLS estimates. The estimated coefficient for our main explanatory variable is 18.7 in the basic specification (column 1), and highly significant. However, there is substantial variation across specifications and, in particular, the estimated coefficient is not significantly different from zero in our preferred specification (column 5).

Let us now turn to the IV estimates, displayed in the bottom panel of Table 3. The point estimate in column 1 is now 41.1, and it remains very stable across specifications. Column 4 controls for changes in economic conditions and a vector of time-invariant amenities. The point estimate is 39.2 , also precisely estimated. Among the set of amenities, we find that the number of cold days and the crime rate have negative and significant coefficients.

The point estimate in our preferred specification (column 5) is a highly significant 44.7 . That is, an inflow of immigrants equal to one percent of the population leads to an increase in the price of housing of roughly 45 euros. This amounts to one third of the average annual increase in housing prices across provinces and years (136 euros, see table 1).

Our IV estimates suggest that OLS is biased downward. That is, controlling for economic conditions, immigrants are attracted to provinces with relatively low increases in housing prices. As a result, there is a spuriously low correlation between immigration and housing price growth. When we instrument for immigration flows using established ethnic networks, we find that the causal effect of immigration into a region is to increase the demand, and thus, the price of housing.

Our estimates for the effect of immigration on house prices are quite close in magnitude to those found in previous studies for the US. Our estimates imply that an immigrant flow equal to $1 \%$ of a region's population leads to a $3.2 \%$ increase in house prices in the region. ${ }^{24}$ Saiz's (2007) instrumental variables results suggest that an inflow of the same magnitude into a US

\footnotetext{
${ }^{24}$ That is, 44.72 euros relative to a national average of 1,384 euros over the period 1998-2008.
} 
metropolitan area would increase prices by $2.9-3.4 \%$. He finds effects on rents that are smaller in size but more precisely estimated. Ottaviano and Peri (2007) find that a 1\% immigration flow increases house prices in the range of 0.65 and $2.4 \%$, also finding smaller but more significant effects on rents. Interestingly, both of these studies also find that OLS estimates are biased downwards.

\subsection{Construction of new dwellings}

We now turn to the effects of immigration on the flow of new residential construction. Our main dependent variable is now the number of housing units built in the current year, normalized by the previous year's population (see equation 2). The right-hand side of the regression is identical to that of the price regressions. The main explanatory variable is the change in the foreign-born population relative to the previous year's population.

These results are presented in Table 4. We also report the results from an additional specification (in Table 5), where we do not normalize immigration or housing flows by population size. We expect the estimated effects of immigration to be very similar in the two alternative models.

The top panels of Tables 4 and 5 present our OLS estimates. In the basic specification (column 1) the point estimates associated to the immigration variable are 0.26 (normalized) and 0.35 in Tables 4 and 5, respectively. In addition to being relatively similar, the point estimates are highly significant in both cases. Turning to our preferred specification (column 5), the OLS estimated coefficients are 0.44 and 0.37 (Tables 4 and 5, respectively), also very similar in the two models and estimated with high precision. 
Let us now turn to the IV estimates, presented in the bottom panel. The estimated coefficient in the basic specification is around 0.4 , regardless of whether we normalize by population size or not. In our preferred specification (column 5), the point estimate is 0.91 in the normalized regression (Table 4) and 0.46 in the non-normalized model (Table 5). The standard deviation of the estimated coefficient is much smaller in the second model (0.38 versus 0.03$)$. As a result, we are more confident about the point estimate based on the model that does not normalize by population (Table 5). ${ }^{25}$ The magnitude of the estimated coefficient implies that an inflow of 10 working-age immigrants leads to the construction of 4.6 new housing units.

As in the price regression, our results here also suggest a downward bias in the OLS estimates. That is, among provinces with similar macroeconomic conditions, immigrants mainly located in provinces with low levels of new construction. The interpretation given earlier (for the price regression) can also account for the bias here. Everything else equal, immigrants will tend to locate in provinces with slow increases in housing prices. The incentives to build new units will also be low in these provinces and, as a result, construction activity will be low. ${ }^{26}$

\subsection{Additional specifications and robustness checks}

This section reports the results of our sensitivity analysis on the main findings presented above. We focus on the IV estimates for the specification that includes region-year dummies (column 5 in Tables 3-5). Table 6 reports the results of several additional specifications. As a benchmark for comparison, column 1 reports our preferred estimates for the effects of increases in the foreign-born population on the price of housing (top panel) and on the construction of new units

\footnotetext{
${ }^{25}$ We test the hypothesis that the estimated coefficients for our preferred specification (column 5) are equal in the two models, and equality cannot be rejected.

${ }^{26}$ In addition, a large share of the aggregate immigration flow located in the main urban centers, where new construction is limited by space constraints.
} 
(middle and bottom panels). Column 2 reports the results of the same specification without weighting each province by initial population. Column 3 uses as main explanatory variable, instead of the immigrant inflow, total population growth in the province (including both natives and immigrants). Finally, column 4 uses the (1-year) lagged increase in the foreign-born population, instead of the contemporaneous measure.

Our preferred estimate for the effect on prices was 44.7 , which is relatively close to the alternative estimates in columns 2 to 4 . The coefficient drops only slightly in the unweighted specification (column 2). When we use total population growth as the main explanatory variable (column 3), the point estimate and the standard error both increase substantially. The reason is that our instrument (predicted changes in the foreign-born population based on ethnic networks) is a better predictor for changes in the foreign-born population than for changes in the total population, which also includes native-born individuals. Finally, the point estimate when we use lagged immigration as our main explanatory variable (column 4) is 50.8, quite precisely estimated. This suggests that some of the effect of immigration on housing prices may take place two years after arrival, even though the bulk of the effect is in the year after arrival.

We now turn to the effects of immigration on the construction of new housing units. We focus on the model that does not normalize by population (bottom panel). The estimate is remarkably stable across specifications, ranging between 0.46 and 0.57 . When we use total population growth, the point estimate is 0.57 (column 3), compared to 0.46 in column 1 . Again, the standard errors associated with the IV estimate are substantially higher when we attempt to predict changes in total population ( 0.05 versus 0.03$)$. The estimated coefficient in column 4 is 0.47 , almost exactly the same magnitude as in the main specification. This suggests that the results are not overly sensitive to our timing assumptions. 


\section{Conclusions}

We show that Spain's large immigration wave over the last decade had an important impact on the housing market, both on prices and quantities. Immigration can explain, to a large extent, why the housing boom in Spain was larger than in the US and in other European countries.

Between 1998 and 2008, the average Spanish province received an immigrant inflow amounting to about $17 \%$ of its initial working-age population. We estimate that, over the whole decade, this population inflow increased house prices by about $52 \%$ and led to the construction of roughly 2 million new housing units. ${ }^{27}$ These figures imply that immigration can account for $30 \%$ of the total increase in prices and $37 \%$ of the total residential construction activity over the period. That is, immigration was responsible for about one third of Spain's spectacular housing market boom over the last decade, both in terms of prices and quantities.

Our estimates are likely to provide a lower bound for the overall effect of immigration on the housing market at the national level. Inflows of foreign-born population into a region may trigger native out-migration to other regions, reducing pressure on the housing market in that region but potentially spilling over to others. ${ }^{28}$ At the national level, immigration may also lead to the outmigration of natives to other countries. However, native out-migration rates have remained very low during this period, suggesting that this type of spillover is unlikely to have played any significant role.

Overall, immigration affected the housing market both through demand and supply. Immigrants increased the demand for housing, either directly as homeowners or indirectly as

\footnotetext{
${ }^{27}$ According to our preferred IV estimates, an increase in the foreign-born population equal to 10 individuals leads to the construction of 4.6 new housing units. Hence, an increase in the foreign-born population equal to $17 \%$ of the initial population corresponds to an increase in housing units equal to $7.8 \%$ of the total initial population, which amounts to 2,083,000 housing units.

${ }^{28}$ However, note that, as is the case in many European countries, internal migration is substantially lower in Spain than in the US. See Bentolila (1997) and Gonzalez and Ortega (2008).
} 
renters. ${ }^{29}$ But, in addition, a large fraction of the (male) immigrants that arrived in Spain over the last decade became employed in the construction sector. ${ }^{30}$ In the absence of immigration, the supply of housing would probably have been much more inelastic, limiting construction activity and GDP growth over the past decade.

With the bust of the Spanish housing market in the midst of the current global economic recession, the rising ranks of unemployed immigrants pose a serious policy challenge. It is yet to be seen whether immigrants will choose to return to their home countries (or re-migrate) or will remain in Spain. Our results suggest that these two responses will have very different consequences for housing markets.

\footnotetext{
${ }^{29}$ According to the 2001 Census, $42 \%$ of Spanish residents with foreign nationality (which can be thought of as recent immigrants) were homeowners.

${ }^{30}$ In 2008, about 600,000 foreign-born individuals were employed in construction, amounting to $25 \%$ of total employment in the sector (Labor Force Survey 2008). In the same year, employment in construction was $12 \%$ of total employment in the economy.
} 


\section{References}

Amuedo-Dorantes, Catalina and Sara de la Rica (2008): "Complements or Substitutes? Immigrant and Native Task Specialization in Spain.” CReAM Discussion Paper 16/08.

Aydemir, Abdurrahman and George Borjas (2005): "Attenuation Bias in Estimating the Wage Impact of Immigration.” Working Paper, Harvard University.

Bentolila, Samuel (1997) "Sticky Labor in Spanish Regions," European Economic Review (Papers and Proceedings) 41.

Card, David (2001) "Immigrant Inflows Native Outflows, and the Local Labor Market Impacts of Higher Immigration” Journal of Labor Economics 19: January, pp. 22-64.

Carrasco, Raquel, Juan F. Jimeno and A. Carolina Ortega (2008). "The Effect of Immigration on the Labor Market Performance of Native-Born Workers: Some Evidence for Spain." Journal of Population Economics 21(3), pp. 627-648.

Cortes, Patricia (2008). "The Effect of Low-skilled Immigration on U.S. Prices: Evidence from CPI Data" Journal of Political Economy 116 (3), 381-422.

Dustmann, Christian, Frattini, T. and Glitz, Albrecht (2008) "The Labour Market Impact of Immigration." Oxford Review of Economic Policy, 24(3).

Farre, Lidia, Gonzalez, Libertad and Ortega, Francesc (2009) "Immigration, Family Responsibilities and the Labor Supply of Skilled Native Women" IZA Discussion Paper No. 4265.

Frattini, T., (2009). "Immigration and prices in the UK." Mimeo.

Gonzalez, L. and Ortega, F. (2008). "How Do Very Open Economies Adjust to Large Immigration Flows? Recent Evidence from Spanish Regions.” IZA Working Paper 3311.

Greulich Erica, Quigley, John, and Raphael, S. (2004) "The Anatomy of Rent Burdens: Immigration, Growth and Rental Housing" Brookings Papers on Urban Affairs, 149-205.

Lewis, E., (2003). "Local, Open Economies Within the US: How Do Industries Respond to Immigration?" Federal Reserve Bank of Philadelphia Working Paper 04-01.

Ottaviano, Gianmarco I.P. and Peri, Giovanni (2005) "Rethinking the Gains from Immigration: Theory and Evidence from the US" NBER Working Paper n. 11672.

Ottaviano, Gianmarco I.P. and Peri, Giovanni (2006) "The Economic Value of Cultural Diversity: Evidence from U.S. Cities” Journal of Economic Geography 6, 9-44. 
Ottaviano, Gianmarco I.P. and Peri, Giovanni (2007) "The Effects of Immigration on US Wages and Rents: A General Equilibrium Approach.” CReAM Discussion Paper No. 13/07.

Saiz, Albert (2003) "Room in the Kitchen for the Melting Pot: Immigration and Rental Prices." Review of Economics and Statistics 85(3):502-521.

Saiz, Albert (2007) "Immigration and Housing Rents in American Cities." Journal of Urban Economics 61:345-371. 


\section{Figures}

Figure 1. Time series of housing prices, new dwellings and foreign-born share

1) Average price of a square meter of housing in euros ( $2^{\text {nd }}$ quarter), 1995-2008

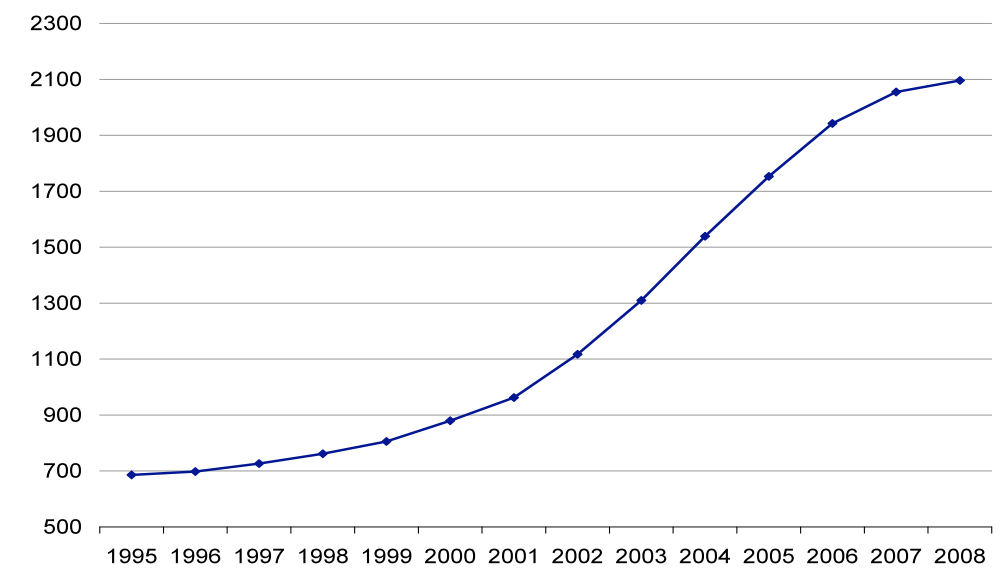

2) New dwellings completed each year (in 1,000), 1995-2008

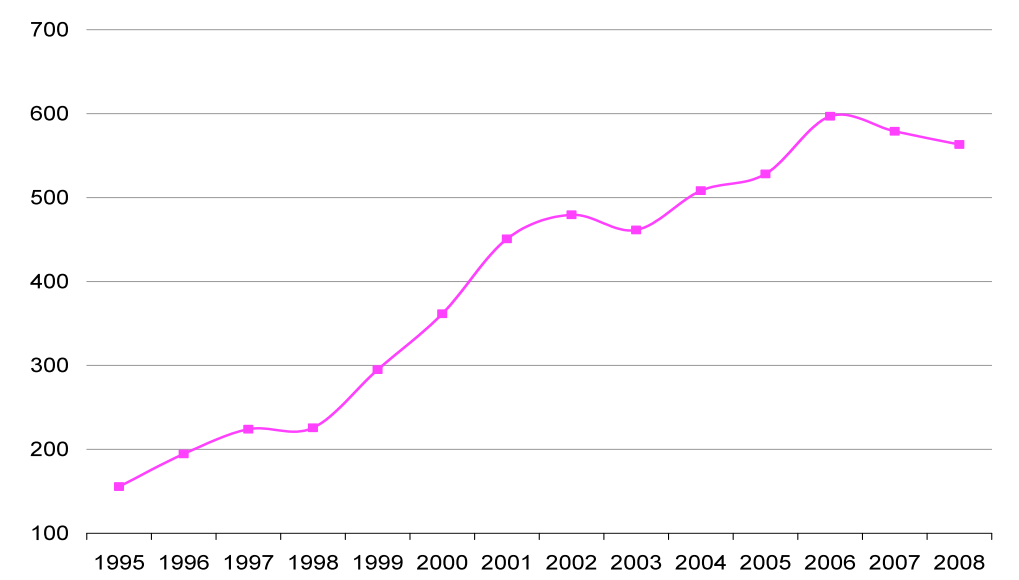

3) Foreign-born share in the working-age population, January $1^{\text {st }}, 1998-2008$

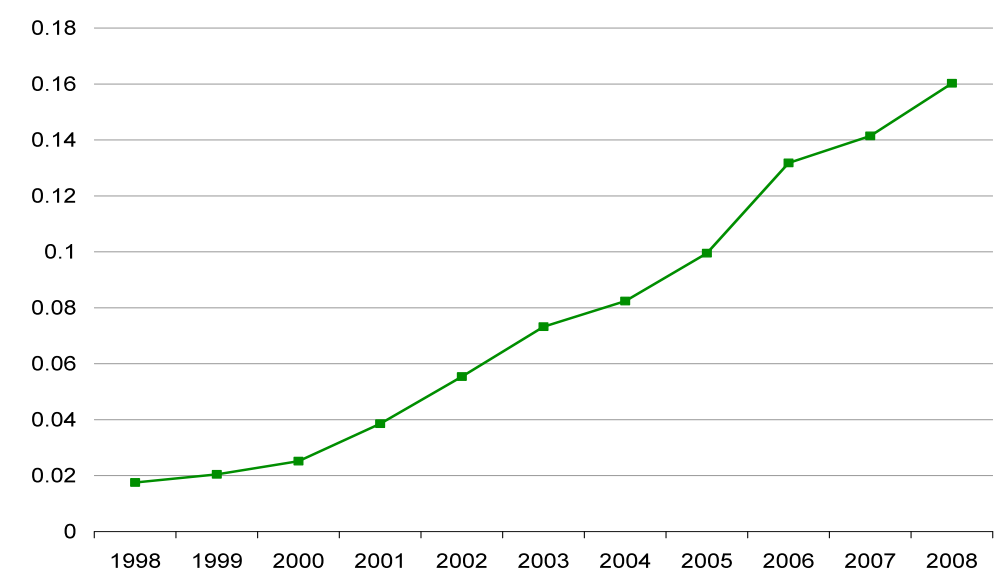


Figure 2. House prices by province, 1998 and 2008

1) Price of a square meter by province in euros, $2^{\text {nd }}$ quarter 1998

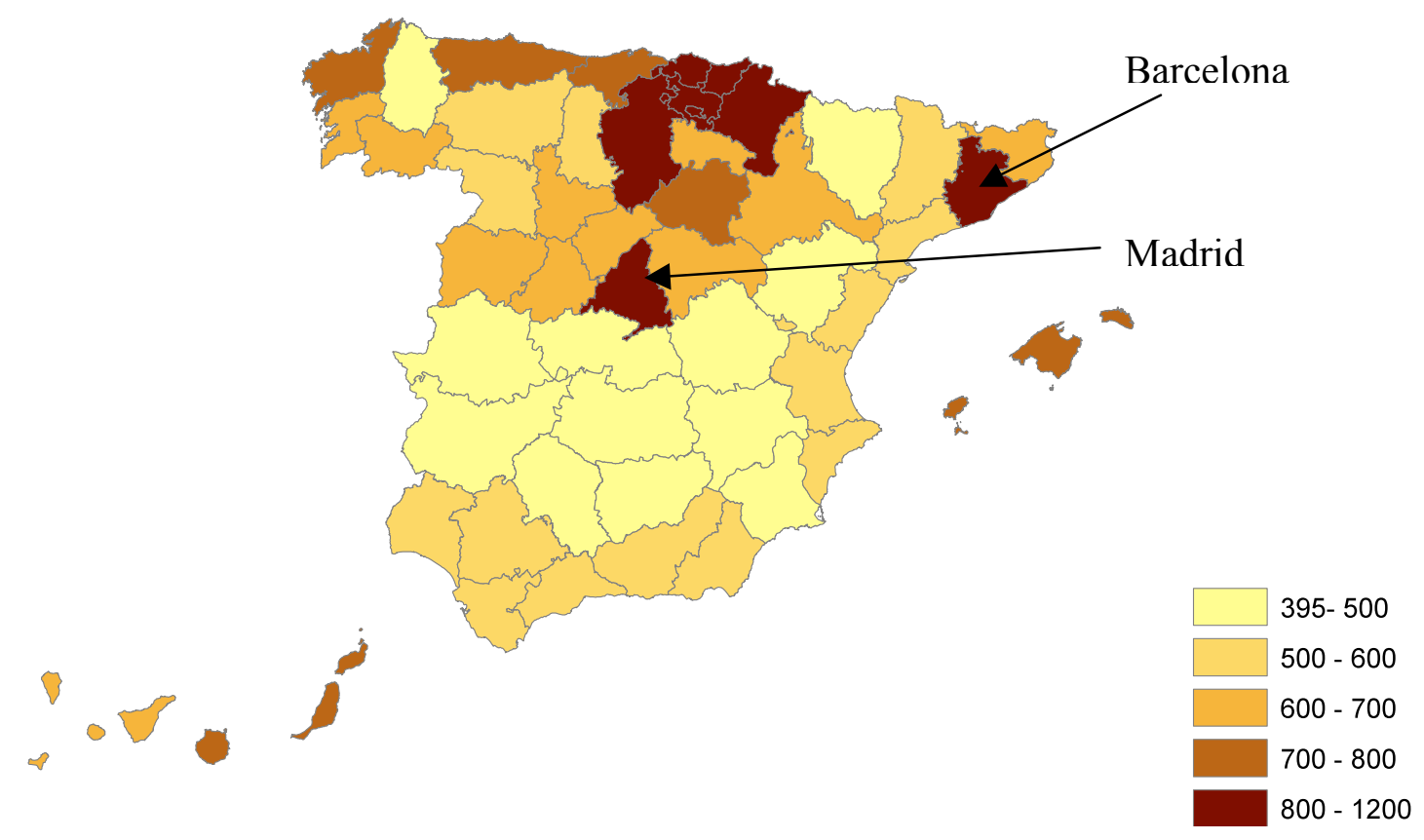

2) Change in the price of a square meter by province in euros, $1998-2008$ ( $2^{\text {nd }}$ quarter)

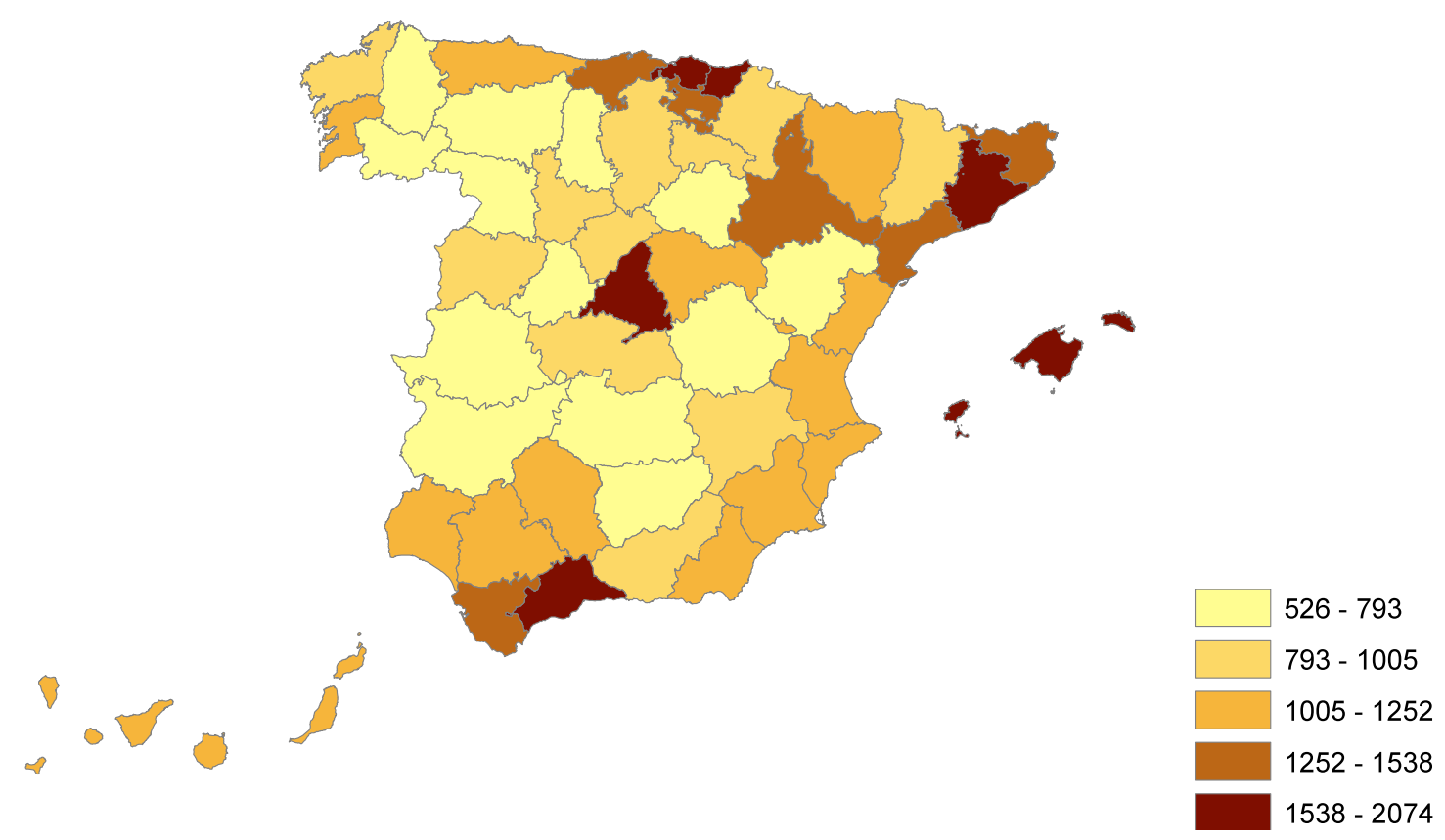


Figure 3. New housing units built by province, 1998-2008 (normalized by 1998 working-age population in thousands)
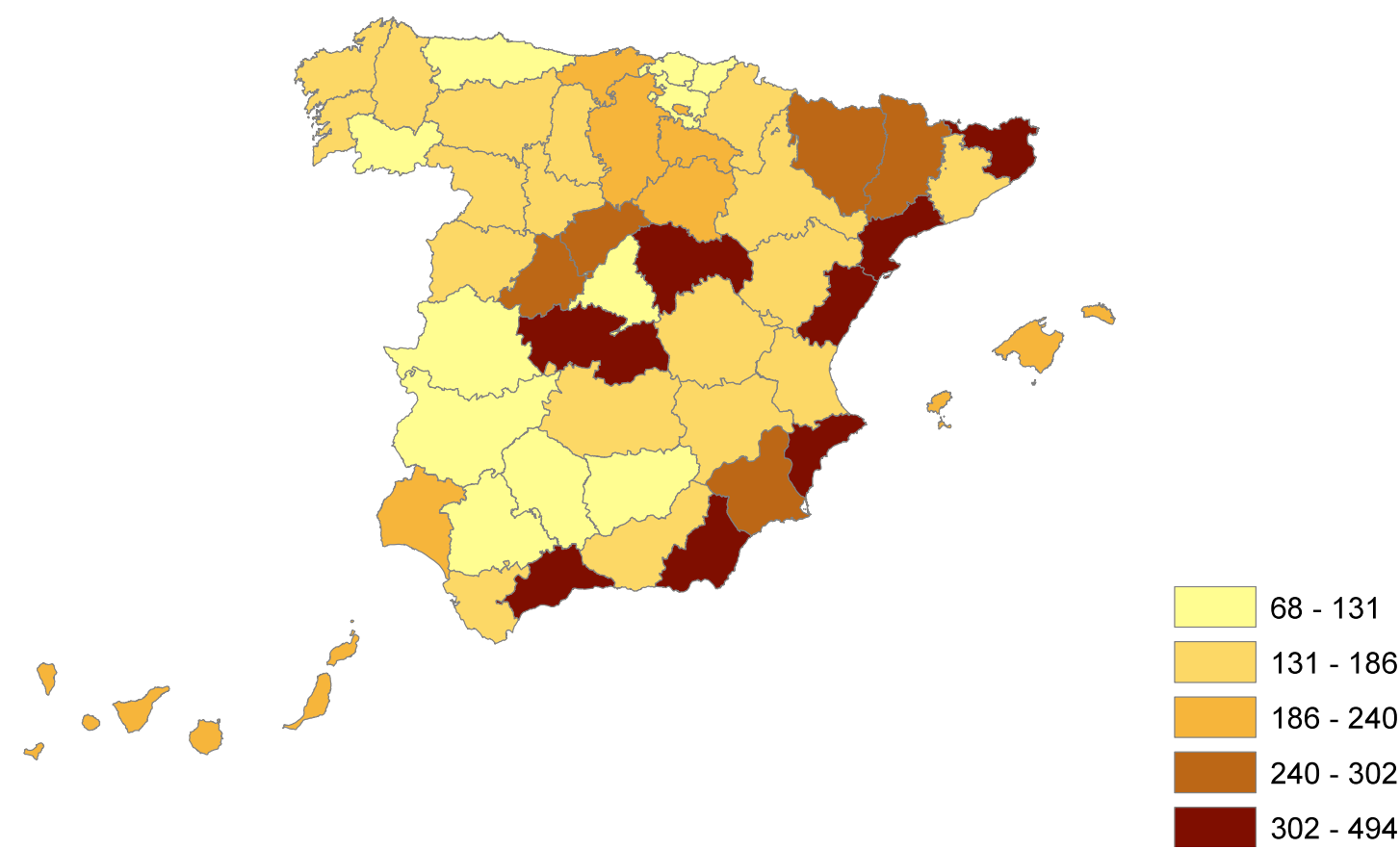

Figure 4. Immigrant concentration by province, 2008
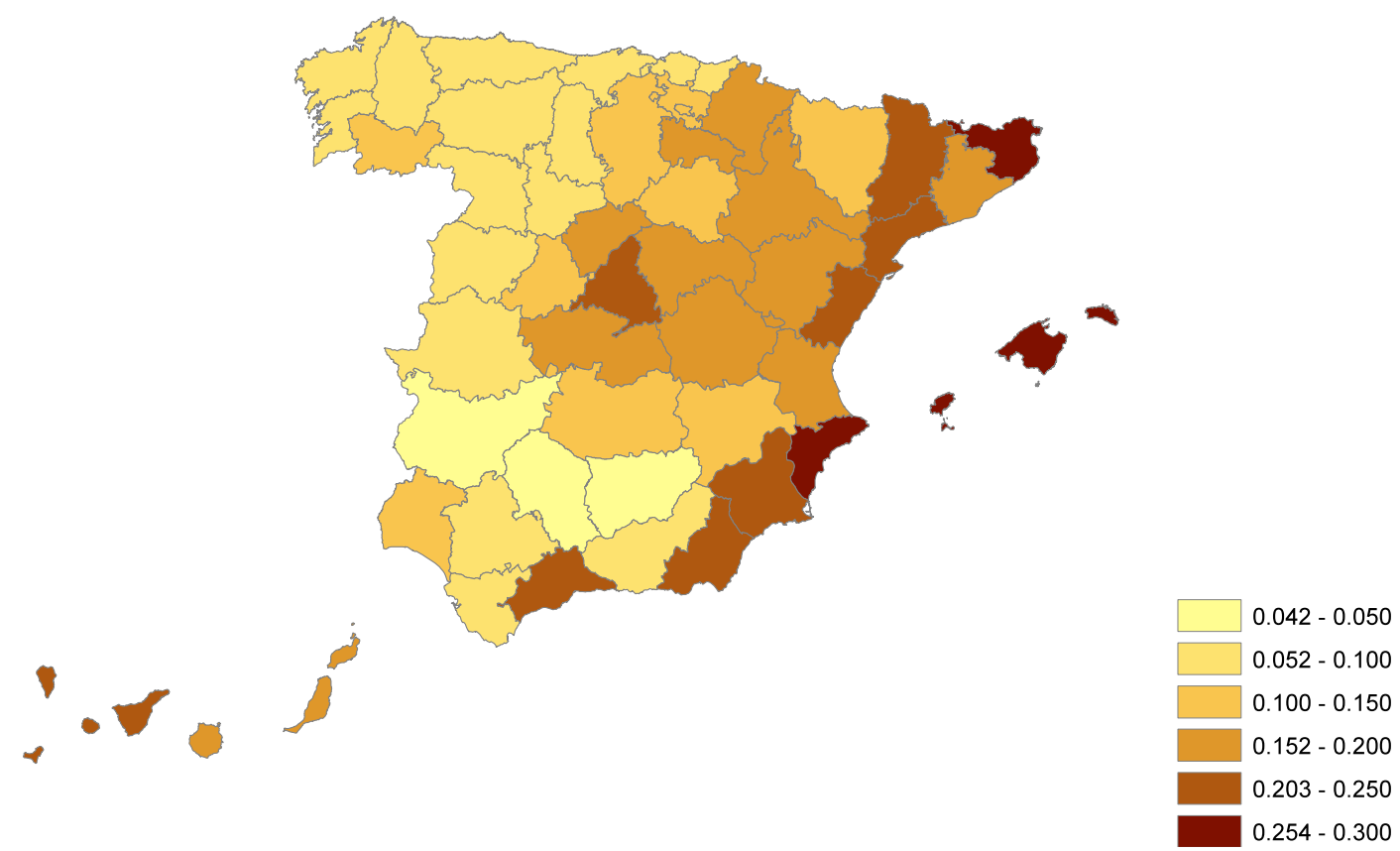

Note: The figure displays the foreign-born share in the working-age population by provinces in Spain, as of January $1^{\text {st }}, 2008$ (Local Registry data). 
Figure 5. Change in the foreign born share and changes in housing prices and quantities, 19982008

1) Price change by province

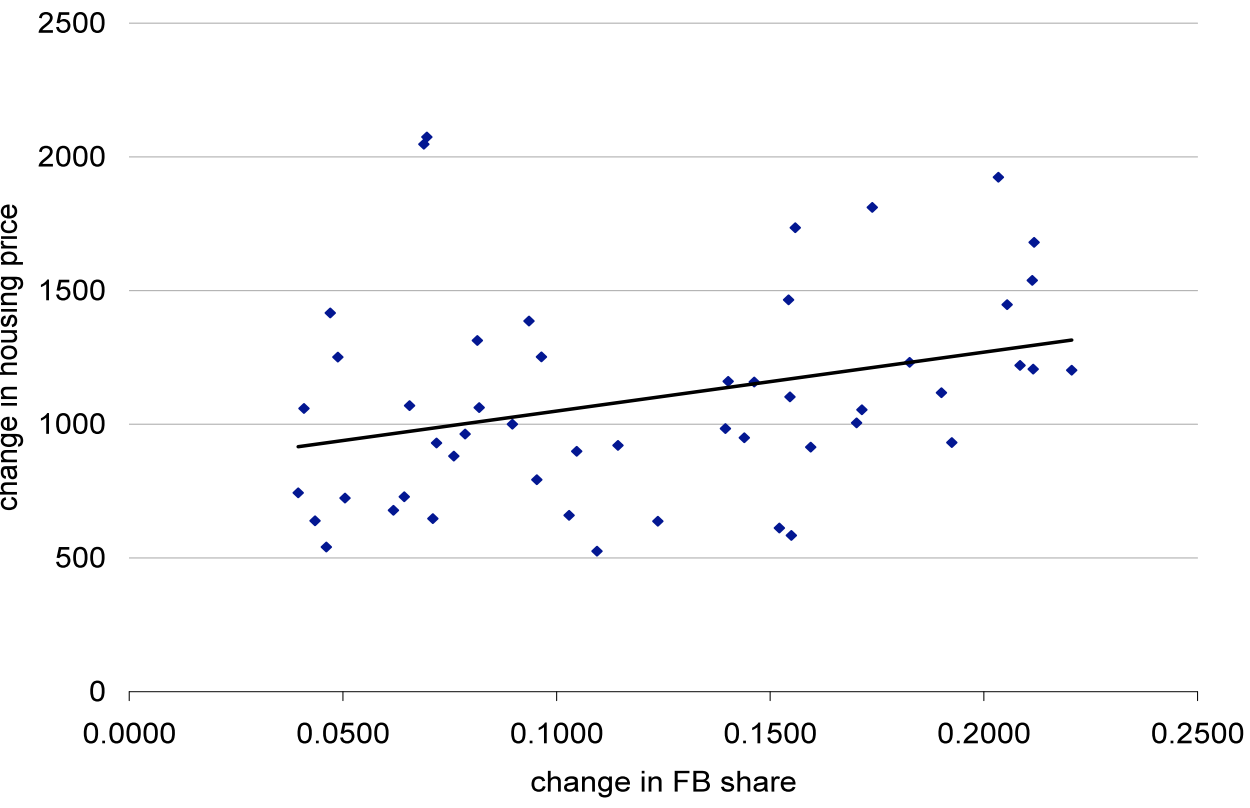

2) New dwellings by province (divided by 1998 population)

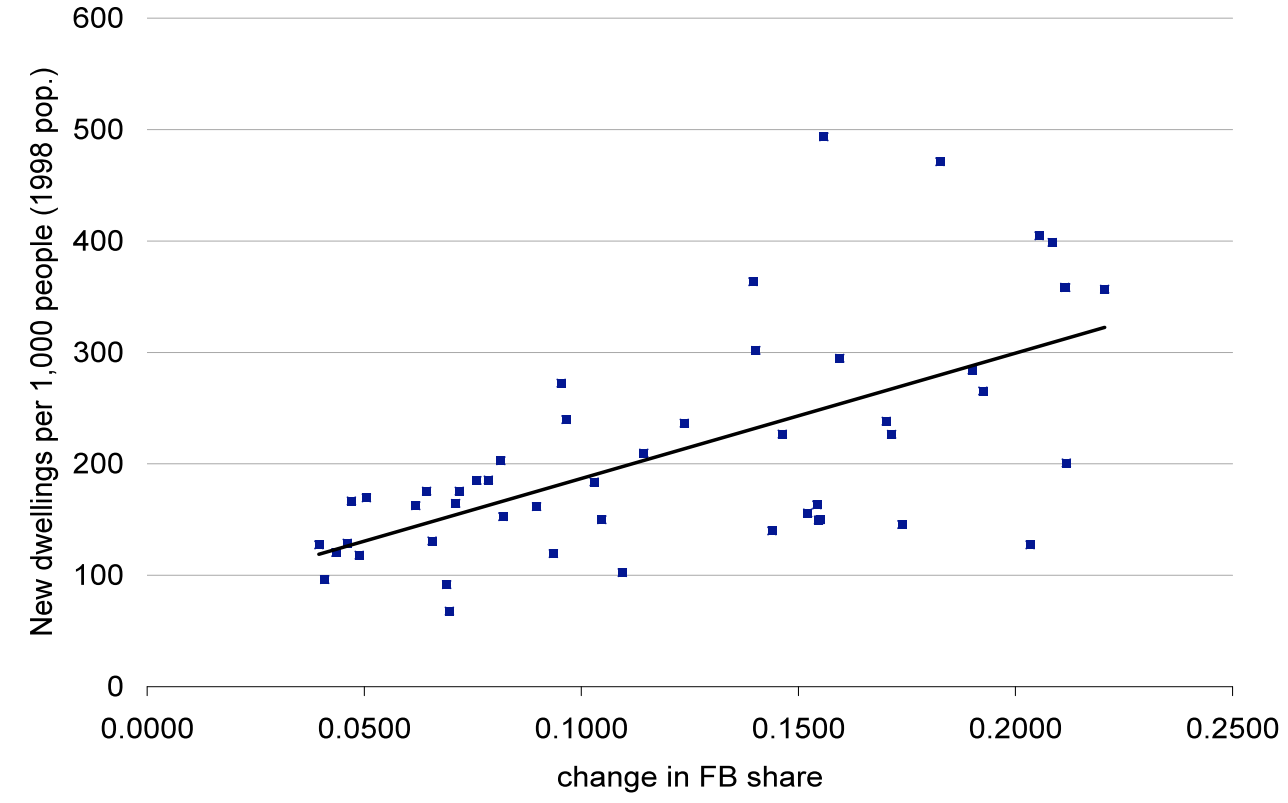

Note: Unweighted linear fits shown. Fifty provinces (Ceuta and Melilla excluded). 


\section{Tables}

Table 1. Descriptive statistics.

\begin{tabular}{|c|c|c|c|c|c|}
\hline Variable & N. Obs. & Mean & Std. Dev. & Min & Max \\
\hline \multicolumn{6}{|l|}{ Change in housing price } \\
\hline \multirow{2}{*}{$\begin{array}{l}\text { New housing units built }(\Delta Q) \\
\text { New units over population } \\
(\Delta Q / \text { Pop })\end{array}$} & 500 & 20,375 & 16,848 & 764 & 64,787 \\
\hline & 500 & 0.0169 & 0.0102 & 0.0034 & 0.0714 \\
\hline \multirow{2}{*}{$\begin{array}{l}\text { Immigration over population } \\
\text { ( } \Delta \text { FB/Pop }) \times 100 \\
\text { Population increase } \\
(\Delta \text { Pop/Pop }) \times 100\end{array}$} & 500 & 1.600 & 1.274 & -0.127 & 7.300 \\
\hline & 500 & 1.644 & 1.382 & -1.111 & 7.363 \\
\hline $\begin{array}{l}\text { Change in employment- } \\
\text { population ratio }\end{array}$ & 500 & 0.0043 & 0.0229 & -0.0849 & 0.0864 \\
\hline $\begin{array}{l}\text { Change in log GDP } \\
\text { Sentenced crimes over }\end{array}$ & 400 & 0.075 & 0.017 & -0.009 & 0.137 \\
\hline $\begin{array}{l}\text { Sentenced crimes over } \\
\text { population }(x 1000)\end{array}$ & 500 & 0.045 & 0.052 & 0.00 & 0.279 \\
\hline Area in square km & 500 & 9121.06 & 4115.11 & 1980.00 & 21766.00 \\
\hline Number of sunny days & 430 & 2719.98 & 413.97 & 1680.00 & 3184.00 \\
\hline Precipitation & 460 & 566.21 & 438.16 & 88.30 & 2450.30 \\
\hline Number of cold days & 470 & 13.23 & 20.03 & 0.00 & 122.00 \\
\hline Province & 500 & 24.97 & 14.29 & 1 & 50 \\
\hline Year & 500 & 2003.64 & 2.87 & 1999 & 2008 \\
\hline
\end{tabular}

Notes: All variables are defined at the annual level. We report population-weighted averages.

The annual change in the price of housing is per square meter. The crime, are and weather variables are time-invariant. 
Table 2. First-stage regressions.

\begin{tabular}{|c|c|c|c|c|c|c|}
\hline Dep. Var: & $\begin{array}{c}\text { (1) } \\
\Delta \text { FB/Pop }\end{array}$ & $\begin{array}{c}(2) \\
\Delta \text { FB/Pop }\end{array}$ & $\begin{array}{c}\text { (3) } \\
\Delta \text { FB/Pop }\end{array}$ & $\begin{array}{c}(4) \\
\Delta \text { FB/Pop }\end{array}$ & $\begin{array}{c}\text { (5) } \\
\Delta \text { FB/Pop }\end{array}$ & $\begin{array}{c}(6) \\
\Delta \mathrm{FB} \\
\end{array}$ \\
\hline $\begin{array}{l}\Delta \mathrm{Z} / \mathrm{Pop}(1998) \\
\text { tstat }\end{array}$ & $\begin{array}{l}0.378^{* * *} \\
(8.193)\end{array}$ & $\begin{array}{c}0.442^{* * *} \\
(8.056)\end{array}$ & $\begin{array}{c}0.352^{* * *} \\
(7.291)\end{array}$ & $\begin{array}{c}0.228^{* * *} \\
(5.847)\end{array}$ & $\begin{array}{c}0.186^{* * *} \\
(5.395)\end{array}$ & \\
\hline $\begin{array}{l}\Delta \mathrm{Z} \\
\text { tstat }\end{array}$ & & & & & & $\begin{array}{c}0.894^{* * *} \\
(19.15)\end{array}$ \\
\hline Macro controls & no & yes & yes & no & no & no \\
\hline Region dummies & no & no & no & yes & yes & no \\
\hline Region-year dummies & no & no & no & no & yes & no \\
\hline Amenities & no & no & yes & no & no & no \\
\hline
\end{tabular}

Note: All specifications include year dummies. All regressions are weighted by 1998 total population in the province. Standard errors are robust. The number of observations is 500 . One asterisk indicates significance at the $90 \%$ level, two indicate $95 \%$, and three, $99 \%$. 
Table 3. Estimates housing prices.

Ordinary Least Squares

\begin{tabular}{lccccc}
\hline & $(1)$ & $(2)$ & $(3)$ & $(4)$ & $(5)$ \\
Dep. Var: & $\Delta \mathrm{P}$ & $\Delta \mathrm{P}$ & $\Delta \mathrm{P}$ & $\Delta \mathrm{P}$ & $\Delta \mathrm{P}$ \\
\hline & & & & & \\
$(\Delta \mathrm{FB} / \mathrm{Pop}) \times 100$ & $18.70^{\star * *}$ & $23.60^{* * *}$ & $18.82^{\star * *}$ & 7.560 & 6.448 \\
& {$[5.136]$} & {$[5.863]$} & {$[5.484]$} & {$[4.819]$} & {$[3.990]$} \\
$\Delta \mathrm{EPR}$ & & -208.3 & -110.0 & & \\
& & {$[177.1]$} & {$[145.5]$} & & \\
InGDP & & $481.3^{* *}$ & & & \\
& & {$[198.2]$} & & & \\
Constant & $63.59^{* * *}$ & $33.71^{* *}$ & $120.3^{* * *}$ & $101.9^{* * *}$ & $42.60^{* * *}$ \\
& {$[9.722]$} & {$[15.67]$} & {$[30.23]$} & {$[22.26]$} & {$[4.936]$} \\
Observations & & & & & \\
R-squared & 500 & 400 & 500 & 500 & 500 \\
\hline
\end{tabular}

Instrumental Variables

\begin{tabular}{lccccc}
\hline & $(1)$ & $(2)$ & $(3)$ & $(4)$ & $(5)$ \\
Dep. Var: & $\Delta \mathrm{P}$ & $\Delta \mathrm{P}$ & $\Delta \mathrm{P}$ & $\Delta \mathrm{P}$ & $\Delta \mathrm{P}$ \\
\hline & & & & & \\
$(\Delta \mathrm{FB} / \mathrm{Pop}) \times 100$ & $41.12^{\star * *}$ & $49.42^{\star * *}$ & $38.62^{\star * *}$ & $39.17^{* *}$ & $44.72^{\star *}$ \\
& {$[11.18]$} & {$[12.03]$} & {$[13.18]$} & {$[17.89]$} & {$[18.58]$} \\
$\Delta \mathrm{EPR}$ & & -64.53 & -34.14 & & \\
& & {$[203.0]$} & {$[154.5]$} & & \\
$\Delta$ InGDP & & 346.4 & & & \\
& & {$[214.5]$} & & & \\
Constant & 51.59 & -2.373 & 101.1 & 72.23 & 39.14 \\
& {$[39.15]$} & {$[41.68]$} & {$[63.28]$} & {$[64.43]$} & {$[62.83]$} \\
Observations & 500 & 400 & 500 & 500 & 500 \\
R-squared & 0.387 & 0.329 & 0.485 & 0.433 & 0.591 \\
\hline & & & & & \\
Region dummies & no & no & no & yes & Yes \\
Region-year dummies & no & no & no & no & Yes \\
Amenities & no & no & yes & no & No \\
\hline
\end{tabular}

Notes: All regressions include year dummies. Amenities include: cold days (below 0 Celsius), rain, sunny days, and crime rate (all in 2000). All regressions are weighted by initial (1998) population in the province. Heteroskedasticity-robust standard errors are shown in brackets.

$* * * \mathrm{p}<0.01, * * \mathrm{p}<0.05, * \mathrm{p}<0.1$ 
Table 4. Estimates construction of new housing units (normalized by population).

\begin{tabular}{|c|c|c|c|c|c|}
\hline Dep. Var: & $\begin{array}{c}(1) \\
\Delta \mathrm{Q} / \mathrm{Pop} \\
\end{array}$ & $\begin{array}{c}(2) \\
\Delta \mathrm{Q} / \mathrm{Pop} \\
\end{array}$ & $\begin{array}{c}(3) \\
\Delta \mathrm{Q} / \mathrm{Pop} \\
\end{array}$ & $\begin{array}{c}(4) \\
\Delta \mathrm{Q} / \mathrm{Pop} \\
\end{array}$ & $\begin{array}{c}(5) \\
\Delta Q / P o p \\
\end{array}$ \\
\hline$\Delta \mathrm{FB} / \mathrm{Pop}$ & $\begin{array}{l}0.259^{* * *} \\
{[0.0662]}\end{array}$ & $\begin{array}{l}0.221^{* * *} \\
{[0.0697]}\end{array}$ & $\begin{array}{l}0.196^{* * *} \\
{[0.0747]}\end{array}$ & $\begin{array}{l}0.280^{* * *} \\
{[0.0696]}\end{array}$ & $\begin{array}{l}0.445^{* * *} \\
{[0.0836]}\end{array}$ \\
\hline$\Delta \mathrm{EPR}$ & & $\begin{array}{l}-0.0145 \\
{[0.0287]}\end{array}$ & $\begin{array}{l}-0.0279 \\
{[0.0258]}\end{array}$ & & \\
\hline$\Delta \mathrm{lnGDP}$ & & $\begin{array}{l}0.121^{* * *} \\
{[0.0376]}\end{array}$ & & & \\
\hline Constant & $\begin{array}{l}0.0159^{\star \star *} \\
{[0.00205]}\end{array}$ & $\begin{array}{c}0.00247 \\
{[0.00326]}\end{array}$ & $\begin{array}{l}0.0140^{* * *} \\
{[0.00369]}\end{array}$ & $\begin{array}{l}0.0108^{\star * *} \\
{[0.00244]}\end{array}$ & $\begin{array}{r}0.00871 \\
{[0.00742}\end{array}$ \\
\hline $\begin{array}{l}\text { Observations } \\
\text { R-squared }\end{array}$ & $\begin{array}{c}500 \\
0.119\end{array}$ & $\begin{array}{c}400 \\
0.166\end{array}$ & $\begin{array}{c}500 \\
0.164\end{array}$ & $\begin{array}{c}500 \\
0.285\end{array}$ & $\begin{array}{c}500 \\
0.348\end{array}$ \\
\hline
\end{tabular}

\begin{tabular}{|c|c|c|c|c|c|}
\hline Dep. Var: & $\begin{array}{c}\text { (1) } \\
\Delta \text { Q/Pop }\end{array}$ & $\begin{array}{c}(2) \\
\Delta \text { Q/Pop }\end{array}$ & $\begin{array}{c}\text { (3) } \\
\Delta \text { Q/Pop }\end{array}$ & $\begin{array}{c}(4) \\
\Delta \mathrm{Q} / \mathrm{Pop}\end{array}$ & $\begin{array}{c}(5) \\
\Delta Q / P o p \\
\end{array}$ \\
\hline$\Delta \mathrm{FB} / \mathrm{Pop}$ & $\begin{array}{l}0.460^{* *} \\
{[0.212]}\end{array}$ & $\begin{array}{l}0.568^{* *} \\
{[0.227]}\end{array}$ & $\begin{array}{l}0.635^{\star *} \\
{[0.281]}\end{array}$ & $\begin{array}{l}0.635^{*} \\
{[0.340]}\end{array}$ & $\begin{array}{l}0.906^{* *} \\
{[0.383]}\end{array}$ \\
\hline$\Delta \mathrm{EPR}$ & & $\begin{array}{l}0.00480 \\
{[0.0373]}\end{array}$ & $\begin{array}{l}-0.00810 \\
{[0.0345]}\end{array}$ & & \\
\hline$\Delta \mathrm{lnGDP}$ & & $\begin{array}{l}0.103^{* * *} \\
{[0.0323]}\end{array}$ & & & \\
\hline Constant & $\begin{array}{l}0.00804^{*} \\
{[0.00472]}\end{array}$ & $\begin{array}{l}-0.00741 \\
{[0.00880]}\end{array}$ & $\begin{array}{c}0.00405 \\
{[0.00770]}\end{array}$ & $\begin{array}{l}-0.00288 \\
{[0.00990]}\end{array}$ & $\begin{array}{l}-0.0165 \\
{[0.0145]}\end{array}$ \\
\hline $\begin{array}{l}\text { Observations } \\
\text { R-squared }\end{array}$ & $\begin{array}{c}500 \\
0.084 \\
\end{array}$ & $\begin{array}{c}400 \\
0.052 \\
\end{array}$ & $\begin{array}{c}430 \\
0.067\end{array}$ & $\begin{array}{c}500 \\
0.223 \\
\end{array}$ & $\begin{array}{c}500 \\
0.277 \\
\end{array}$ \\
\hline $\begin{array}{l}\text { Region dummies } \\
\text { Region-year dummies } \\
\text { Amenities }\end{array}$ & $\begin{array}{l}\text { no } \\
\text { no } \\
\text { no }\end{array}$ & $\begin{array}{l}\text { no } \\
\text { no } \\
\text { no }\end{array}$ & $\begin{array}{c}\text { no } \\
\text { no } \\
\text { yes } \\
\end{array}$ & $\begin{array}{l}\text { yes } \\
\text { no } \\
\text { no }\end{array}$ & $\begin{array}{c}\text { yes } \\
\text { yes } \\
\text { no }\end{array}$ \\
\hline
\end{tabular}

Notes: All regressions include year dummies. Amenities include: cold days (below 0 Celsius), rain, sunny days, and crime rate (all in 2000). All regressions are weighted by initial (1998) population in the province. Heteroskedasticity-robust standard errors are shown in brackets.

$* * * \mathrm{p}<0.01, * * \mathrm{p}<0.05, * \mathrm{p}<0.1$ 
Table 5. Estimates construction of new housing units

Ordinary Least Squares

\begin{tabular}{|c|c|c|c|c|c|}
\hline & (1) & (2) & (3) & (4) & (5) \\
\hline Dep. Var: & $\Delta \mathrm{Q}$ & $\Delta Q$ & $\Delta \mathrm{Q}$ & $\Delta \mathrm{Q}$ & $\Delta Q$ \\
\hline$\Delta \mathrm{FB}$ & $\begin{array}{l}0.347^{* * *} \\
{[0.0366]}\end{array}$ & $\begin{array}{l}0.366^{* * *} \\
{[0.0363]}\end{array}$ & $\begin{array}{l}0.287^{* * *} \\
{[0.0366]}\end{array}$ & $\begin{array}{l}0.280^{* * *} \\
{[0.0371]}\end{array}$ & $\begin{array}{l}0.369^{* * *} \\
{[0.0327]}\end{array}$ \\
\hline$\Delta \mathrm{EPR}$ & & $\begin{array}{l}-31685 \\
{[42313]}\end{array}$ & $\begin{array}{l}-26686 \\
{[27687]}\end{array}$ & & \\
\hline$\Delta \operatorname{lnGDP}$ & & $\begin{array}{c}129564^{* * *} \\
{[38791]}\end{array}$ & & & \\
\hline Constant & $\begin{array}{l}5306^{\star *} \\
{[2509]}\end{array}$ & $\begin{array}{c}3715 \\
{[3838]}\end{array}$ & $\begin{array}{l}9805^{\star *} \\
{[4544]}\end{array}$ & $\begin{array}{c}11627^{* * *} \\
{[3601]}\end{array}$ & $\begin{array}{c}6062 \\
{[4322]}\end{array}$ \\
\hline $\begin{array}{l}\text { Observations } \\
\text { R-squared }\end{array}$ & $\begin{array}{c}500 \\
0.595\end{array}$ & $\begin{array}{c}400 \\
0.636\end{array}$ & $\begin{array}{c}500 \\
0.693\end{array}$ & $\begin{array}{c}500 \\
0.678\end{array}$ & $\begin{array}{c}500 \\
0.772\end{array}$ \\
\hline \multicolumn{6}{|l|}{ Instrumental Variables } \\
\hline VARIABLES & $\begin{array}{l}1) \\
\Delta Q \\
\end{array}$ & $\begin{array}{l}(2) \\
\Delta Q \\
\end{array}$ & $\begin{array}{l}(3) \\
\Delta Q \\
\end{array}$ & $\begin{array}{l}4) \\
\Delta Q \\
\end{array}$ & $\begin{array}{l}(5) \\
\Delta Q \\
\end{array}$ \\
\hline$\Delta \mathrm{FB}$ & $\begin{array}{l}0.395^{\star * *} \\
{[0.0447]}\end{array}$ & $\begin{array}{l}0.421^{* * *} \\
{[0.0443]}\end{array}$ & $\begin{array}{l}0.330^{* * *} \\
{[0.0473]}\end{array}$ & $\begin{array}{l}0.383^{* * *} \\
{[0.0455]}\end{array}$ & $\begin{array}{l}0.462^{* * *} \\
{[0.0329]}\end{array}$ \\
\hline$\Delta \mathrm{EPR}$ & & $\begin{array}{l}-28481 \\
{[45742]}\end{array}$ & $\begin{array}{l}-24265 \\
{[26806]}\end{array}$ & & \\
\hline$\Delta \mathrm{lnGDP}$ & & $\begin{array}{c}129049^{* \star *} \\
{[38040]}\end{array}$ & & & \\
\hline Constant & $\begin{array}{c}2590 \\
{[3309]}\end{array}$ & $\begin{array}{l}-8622^{*} \\
{[4600]}\end{array}$ & $\begin{array}{l}7119^{* *} \\
{[3128]}\end{array}$ & $\begin{array}{l}828.0 \\
{[4569]}\end{array}$ & $\begin{array}{l}-5708 \\
{[5132]}\end{array}$ \\
\hline $\begin{array}{l}\text { Observations } \\
\text { R-squared }\end{array}$ & $\begin{array}{c}500 \\
0.584 \\
\end{array}$ & $\begin{array}{c}400 \\
0.623 \\
\end{array}$ & $\begin{array}{c}430 \\
0.667 \\
\end{array}$ & $\begin{array}{c}500 \\
0.654 \\
\end{array}$ & $\begin{array}{c}500 \\
0.758 \\
\end{array}$ \\
\hline Region dummies & no & no & no & yes & yes \\
\hline Region-year dummies & no & no & no & no & yes \\
\hline Amenities & no & no & yes & no & no \\
\hline
\end{tabular}

Notes: All regressions include year dummies. Amenities include: cold days (below 0 Celsius), rain, sunny days, and crime rate (all in 2000). All regressions are weighted by initial (1998) population in the province. Heteroskedasticity-robust standard errors are shown in brackets.

$* * * \mathrm{p}<0.01, * * \mathrm{p}<0.05, * \mathrm{p}<0.1$ 
Table 6. Robustness checks.

\begin{tabular}{|c|c|c|c|c|}
\hline Dep. Var: & $\begin{array}{l}(1) \\
\Delta P\end{array}$ & $\begin{array}{l}(2) \\
\Delta \mathrm{P}\end{array}$ & $\begin{array}{l}(3) \\
\Delta \mathrm{P}\end{array}$ & $\begin{array}{l}(4) \\
\Delta \mathrm{P}\end{array}$ \\
\hline$(\Delta \mathrm{FB} / \mathrm{Pop}) \times 100$ & $\begin{array}{l}44.72^{* *} \\
{[18.58]}\end{array}$ & $\begin{array}{l}42.07^{*} \\
{[23.02]}\end{array}$ & & \\
\hline ( $($ Pop/Pop)x100 & & & $\begin{array}{l}69.62^{*} \\
{[40.96]}\end{array}$ & \\
\hline $\operatorname{lag}(\Delta \mathrm{FB} / \mathrm{Pop}) \times 100$ & & & & $\begin{array}{l}50.85^{\star *} \\
{[20.65]}\end{array}$ \\
\hline $\begin{array}{l}\text { Observations } \\
\text { R-squared }\end{array}$ & $\begin{array}{c}500 \\
0.591\end{array}$ & $\begin{array}{c}500 \\
0.420\end{array}$ & $\begin{array}{c}500 \\
0.182\end{array}$ & $\begin{array}{c}450 \\
0.554\end{array}$ \\
\hline Dep. Var: & $\begin{array}{c}\text { (1) } \\
\Delta \text { Q/Pop }\end{array}$ & $\begin{array}{c}(2) \\
\Delta \mathrm{Q} / \mathrm{Pop}_{\mathrm{op}}\end{array}$ & $\begin{array}{c}\text { (3) } \\
\Delta \text { Q/Pop }\end{array}$ & $\begin{array}{c}(4) \\
\Delta \text { Q/Pop }\end{array}$ \\
\hline$(\Delta \mathrm{FB} / \mathrm{Pop}) \times 100$ & $\begin{array}{l}0.906^{* *} \\
{[0.383]}\end{array}$ & $\begin{array}{l}0.930^{* *} \\
{[0.473]}\end{array}$ & & \\
\hline$(\Delta \mathrm{Pop} / \mathrm{Pop}) \times 100$ & & & $\begin{array}{l}1.411^{* *} \\
{[0.549]}\end{array}$ & \\
\hline $\operatorname{lag}(\Delta \mathrm{FB} / \mathrm{Pop}) \times 100$ & & & & $\begin{array}{l}0.633^{*} \\
{[0.335]}\end{array}$ \\
\hline $\begin{array}{l}\text { Observations } \\
\text { R-squared }\end{array}$ & $\begin{array}{c}500 \\
0.277 \\
\end{array}$ & $\begin{array}{c}500 \\
0.301 \\
\end{array}$ & $\begin{array}{c}500 \\
0.037 \\
\end{array}$ & $\begin{array}{c}450 \\
0.301\end{array}$ \\
\hline Dep. Var: & $\begin{array}{l}(1) \\
\Delta Q\end{array}$ & $\begin{array}{l}(2) \\
\Delta Q\end{array}$ & $\begin{array}{l}\text { (3) } \\
\Delta Q\end{array}$ & $\begin{array}{l}(4) \\
\Delta Q\end{array}$ \\
\hline$\Delta \mathrm{FB}(\mathrm{x} 100)$ & $\begin{array}{l}0.462^{* * *} \\
{[0.0329]}\end{array}$ & $\begin{array}{l}0.503^{* * *} \\
{[0.0516]}\end{array}$ & & \\
\hline$\Delta \mathrm{Pop}(\mathrm{x} 100)$ & & & $\begin{array}{l}0.570^{* * *} \\
{[0.0507]}\end{array}$ & \\
\hline $\operatorname{lag}(\Delta \mathrm{FB}) \times 100$ & & & & $\begin{array}{l}0.477^{\star * *} \\
{[0.0327]}\end{array}$ \\
\hline $\begin{array}{l}\text { Observations } \\
\text { R-squared }\end{array}$ & $\begin{array}{c}500 \\
0.758\end{array}$ & $\begin{array}{c}500 \\
0626\end{array}$ & $\begin{array}{c}500 \\
0738\end{array}$ & $\begin{array}{c}450 \\
0744\end{array}$ \\
\hline
\end{tabular}

Notes: All regressions in this table include region-year dummies and are estimated by instrumental variables. All regressions are weighted by initial population in the province, except for column 2. Column 1 is the benchmark (preferred estimates). Column 2 is unweighted. Column 3 uses total population growth as the main explanatory variable. Column 4 uses lagged immigration. Heteroskedasticity-robust standard errors shown in brackets. $* * * \mathrm{p}<0.01,{ }^{* *} \mathrm{p}<0.05, * \mathrm{p}<0.1$. 